DOI 10.15290/cnisk.2016.01.01.08

\title{
Luki identyfikacji etnicznej w spisach powszechnych państw Grupy Wyszehradzkiej: kobiety vs mężczyźni
}

\begin{abstract}
Streszczenie
Artykuł prezentuje wyniki spisów powszechnych przeprowadzonych w Polsce, Czechach, Słowacji i Węgrzech (Grupa V4) w 2011 roku. Państwa Grupy Wyszehradzkiej były zawsze częścia tej samej cywilizacji, opartej o wspólne wartości materialne i intelektualne oraz wspólne korzenie w różnych tradycjach wyznaniowych, które wyrażają wolę utrzymania i wzmacniania utrwalonych powiązań. Narodowe spisy powszechne ludności i mieszkań w krajach V4 w roku 2011 były pierwszymi po akcesji tych państw do Unii Europejskiej. Spisy powszechne sa ważnym momentem w życiu każdego narodu, w którym to państwo pyta swych obywateli, między innymi, o identyfikację etniczną. W poniższym tekście autor poddaje analizie zjawisko luki identyfikacji etnicznej, ujawniające się w trakcie spisów: fenomen obejmujący 4,95 mln obywateli Grupy Wyszehradzkiej, którzy zrezygnowali z możliwości ujawnienia swej tożsamości narodowej. Pytania o przynależność etniczna, w tym podwójna tożsamość narodowościową były w trakcie spisu - w szczególności w Czechach - nieobligatoryjnymi, udzielenie odpowiedzi na pytanie o etniczność uzależnione było od woli respondentów i respondentek.

Słowa kluczowe: identyfikacja etniczna • spisy powszechne 2011 • mniejszości narodowe $\bullet$ Grupa Wyszehradzka
\end{abstract}




\title{
THE ETHNIC IDENTIFICATION GAPS IN THE NATIONAL CENSUSES OF THE VISEGRAD GROUP COUNTRIES: WOMEN VS. MEN
}

\begin{abstract}
The article presents the results of the 2011 National Censuses in Poland, the Czech Republic, Slovakia and Hungary (V4). These countries have always been part of a single civilization sharing cultural and intellectual values and common roots in diverse religious traditions, which they wish to preserve and further strengthen. The 2011 Censuses of Population and Housing were the first researches performed since V4`s accession to the European Union. Censuses constitute important moments in the life of a nation, as this is when the State asks its citizens - among other questions - "What's your nationality"? In this study the author examines the phenomenon of the ethnic gap identification: 4,95 million citizens of the Visegrad Group who chose not to respond the questions relating to national and ethnic identity. Ethnicity, including dual ethnicity, was recorded - especially in the Czech Republic - as freely declared by the respondent's wishes and on a voluntary basis, so a respondent could also refuse to report his or her ethnicity.
\end{abstract}

Keywords: ethnic identification • 2011 censuses • ethnic minority • the Visegrad Group

\section{Wprowadzenie}

Spisy powszechne ludności sa unikatowym źródłem informacji na temat mieszkańców państw przeprowadzających tę złożoną, administracyjna operację. Podstawowym ich celem jest ustalenie dokładnej liczby ludności oraz poznanie wybranych cech populacji (demograficznych, społecznych, ekonomicznych, geograficznych). Spis powszechny jest przedsięwzięciem badawczym nieporównywalnym $z$ żadnym innym analizowanym na gruncie nauk społecznych ${ }^{1}$. Portret społeczeństwa dostarczany przez ten instrument poznawczy jest wartościowy - ze względu na zasięg badania, jego zakres tematyczny, potencjał możliwych zastosowań zebranych danych. I chociaż najsprawniej przeprowadzone ewi-

1 M. Krywult-Albańska, Spis powszechny jako źródło informacji o ludności, „Studia Socjologiczne” 2012, nr 4, s. 102. 
dencje ludności nie dostarczaja danych w pełni odzwierciedlajacych stan zastany, umożliwiaja pozyskanie szczególnie cennych informacji, niezbędnych $\mathrm{w}$ analizach demograficznych, społecznych i gospodarczych ${ }^{2}$. Wyniki spisów powszechnych sa źródłem wiedzy, która ma zastosowanie w administracji, polityce, edukacji, kulturze oraz dziennikarstwie.

Celem niniejszego tekstu jest omówienie występującego w czasie spisu powszechnego zjawiska rezygnacji części obywateli z możliwości udzielania informacji na temat własnej przynależności etnicznej (w skrócie: luka identyfikacji narodowościowej). W sposób szczegółowy zaprezentowane zostaną dane, odnoszące się do luki identyfikacji narodowo-etnicznej kobiet i mężczyzn z Polski, Węgier, Czech oraz Słowacji, państw o zbliżonych doświadczeniach historycznych, zbieżnych celach politycznych, współpracujących od 25 lat w formule Grupy Wyszehradzkiej.

W wielu państwach, najczęściej wielonarodowych oraz tych o tradycjach migranckich, rutynowym elementem spisu jest komponent etniczny. Pytania o przynależność do grupy etnicznej na kontynencie europejskim sa powszechnie stosowane w spisach państw Europy Środkowej i Wschodniej (zdecydowana większość krajów Europy Zachodniej, m.in. poza Wielką Brytanią czy Irlandia, nie umieszcza w zestawie zagadnień spisowych pytania o przynależność narodowa). Władze krajów, które pozyskuja dane na temat tożsamości narodowościowej, zbieraja również informacje na temat języka domowego swych mieszkańców lub/i ich przynależności religijnej. Oczywiście należy mieć na uwadze, iż wszelkie statystyki narodowościowe (podobnie jak też wyznaniowe) - w tym zebrane $\mathrm{w}$ trakcie spisu powszechnego - dotycza kwestii wrażliwych, subiektywnych. Sa one tym samym trudno mierzalne, nie muszą odzwierciedlać rzeczywistej struktury etnicznej (bądź konfesyjnej), a ich wyniki najczęściej wywołuja emocje, skutkuja pojawieniem się różnic interpretacyjnych ${ }^{3}$.

2 E. Gołata, Spis ludności i prawda, „Studia Demograficzne” 2012, nr 1(161), s. 51 .

3 M. Barwiński, Struktura narodowościowa Polski $w$ świetle wyników spisu powszechnego z 2011 roku, „Przegląd Geograficzny” 2014, t. 86, z. 2, s. 237. 


\section{Instytucja spisu powszechnego w państwach Grupy Wyszehradzkiej}

Rozporzadzenie nr 763/2008 Parlamentu Europejskiego i Rady UE ustanawia wspólne zasady dotyczace dostarczania przez państwa Unii Europejskiej co dziesięć lat wyczerpujacych danych na temat ludności i mieszkań ${ }^{4}$. W załączniku do tego aktu wymienione sa obligatoryjne tematy, objęte spisem powszechnym dla właściwych poziomów geograficznych NUTS (nomenklatura jednostek terytorialnych UE do celow statystycznych) w przypadku ludności kraje Zjednoczonej Europy na poziomie krajowym są zobowiązane zebrać informacje odnośnie: płci, wieku, stanu cywilnego, bieżącej aktywności ekonomicznej, zawodu, statusu zatrudnienia, poziomu wykształcenia, kraju urodzenia, posiadanego obywatelstwa. Identyfikacja etniczno-narodowa, język czy wyznanie mieszkańców nie znalazły się w tym obligatoryjnym katalogu danych, pozyskiwanych w trakcie spisów powszechnych. Państwa członkowskie, realizując obowiązek dostarczenia wiarygodnych oraz szczegółowych danych Komisji Europejskiej (a właściwie jej urzędowi odpowiedzialnemu za publikację danych statystycznych całej UE - Eurostat), moga opierać dane statystyczne na różnych źródłach wiedzy, m.in. tradycyjnych spisach powszechnych, kombinacji tradycyjnych spisów $z$ badaniami reprezentacyjnymi czy odpowiednich badaniach opartych na próbie rotacyjnej. Narodowe spisy powszechne ze względów ekonomicznych nie sa najczęściej realizowane według konwencji tradycyjnego zewidencjonowania ludności. Spis w Polsce $\mathrm{w}$ roku 2011, dla przykładu, był realizowany metoda mieszana, tj. z wykorzystaniem systemów informacyjnych administracji publicznej oraz danych zebranych w badaniu pełnym i badaniu reprezentacyjnym (obejmującym 20 proc. wylosowanych mieszkań, tj. ok. 2,7 mln spośród 13,5 mln mieszkań).

4 Rozporzadzenie (WE) Parlamentu Europejskiego i Rady $\mathrm{nr} 763 / 2008 \mathrm{z}$ dnia 9 lipca 2008 r. $w$ sprawie spisów powszechnych ludności i mieszkań, Dziennik Urzędowy Unii Europejskiej, L218/14. 
Państwa należące do Grupy Wyszehradzkiej (Visegrad Group) ${ }^{5}$ łączy sąsiedztwo, podobne uwarunkowania geopolityczne, wspólna historia, pokrewna kultura. W optyce etnicznej współczesna Polska, Węgry, Czechy i Słowacja sa strukturami o różnym stopniu wewnętrznego zróżnicowania narodowościowego, co może prowadzić $\mathrm{w}$ trakcie spisu powszechnego do występowania istotnej różnicy w zakresie skali ujawniania przez rezydentów swojej przynależności etnicznej. Identyfikacja etniczno-narodowa (w spisie w Polsce posłużono się kategoriami: narodowość oraz przynależność do narodu/ wspólnoty etnicznej; na Węgrzech wystapił termin nemzetiséghez oznaczajacymi narodowość; w Czechach użyto terminu národnost, a na Słowacji posłużono się nomenklaturą národnost' - również oznaczających narodowość ${ }^{7}$ ) jest jednym z wymiarów społeczno-kulturowych, charakteryzujących mieszkańców Grupy Wyszehradzkiej, a poddawanych poznaniu w trakcie spisów powszechnych (w ramach tego bloku społecznokulturowego sa także: język kontaktów domowych, język ojczysty, wyznanie religijne). W Polsce przynależność do narodu dominujacego podczas ostatniego spisu zadeklarowało 97,1\% mieszkańców (94,8\% wyłącznie polska narodowość, $2,3 \%$ polską i równocześnie niepolska narodowość) ${ }^{8}$. Na Węgrzech tożsamość madziarską zaznaczyło 86,6\% rezydentów ${ }^{9}$, na Słowacji 80,7\% uczestników spisu zadeklarowało przynależność do narodu dominującego ${ }^{10}$, zaś

5 Potocznym określeniem grupy jest akronim V4. Celem utworzenia Grupy Wyszehradzkiej było pogłębienie kooperacji w zakresie budowy demokratycznych struktur państwowych oraz wolnorynkowej gospodarki, a docelowo uczestnictwo $\mathrm{w}$ procesie integracji europejskiej. Za date powstania V4 przyjmuje się 15 II 1991 r., kiedy to prezydent L. Wałęsa (Polska), prezydent V. Havel (Czechosłowacja) i premier J. Antall (Węgry) podpisali deklarację o warunkach wzajemnej współpracy. Zob. www.msz.gov.pl/pl/polityka_zagraniczna/europa/grupa_wyszehradzka, [Dostęp: 10.8.2008].

${ }_{6}$ Zob. pytanie 34 oraz $35 \mathrm{w}$ kwestionariuszu spisowym, [Dostęp: 10.08.2016]. Dostępny w World Wide Web: <http://bit.ly/2fCkRs8>

7 Zob. pytanie 11 czeskiego spisu a.d. 2011 oraz pytanie $\mathrm{nr} 20 \mathrm{w}$ słowackim kwestionariuszu, [Dostęp: 10.08.2016]. Dostępny w World Wide Web: $<$ http://bit.ly/2gIs 1wQ>.

8 Struktura narodowo-etniczna, językowa i wyznaniowa ludności Polski. Narodowy Spis Powszechny Ludności i Mieszkań 2011, GUS, Warszawa 2015, s. 29.

9 Zob. tablica 1.1.6.1, [Dostęp: 13.08.2016]. Dostępny w World Wide Web: $<$ http:// bit.ly/2gIA2li>

10 [Dostęp: 13.08.2016]. Dostępny w World Wide Web: <http://bit.ly/2gpI9PG>. 
w Czechach ten odsetek wyniósł 64,3\%11. W świetle wyników spisu $\mathrm{w}$ Polsce największą nieustawowa mniejszościa narodowościową są Ślązacy $(2,2 \%$ deklaracji identyfikacji wyłącznie śląskiej lub dualnej: śląskiej i innej), na Węgrzech najliczniejsza grupa mniejszościowa sa Romowie $(3,1 \%)$, w Czechach Morawianie (5,0\%), zaś na Słowacji żyje znacząca diaspora węgierska $(8,5 \%)$.

Spis powszechny nie zawsze przebiega sprawnie - ze względu na negatywny stosunek pewnej części społeczeństwa, najczęściej przedstawicieli mniejszości. W przypadku spisów przeprowadzonych w roku 2011 w państwach Grupy Wyszehradzkiej nieincydentalne trudności wystapiły na Słowacji. Największe przeszkody uaktywniły się w stolicy kraju, przede wszystkim w dzielnicy blokowisk Petržalka, gdzie $z$ pracy przy spisie $-z$ powodu bezpośredniego zagrożenia zdrowia (groźby, agresja) - zrezygnowało ponad stu rachmistrzów. W środkowej części kraju, w mieście Martin, mimo dużego zainteresowania praca przy spisie, nie było chętnych na rozdawanie formularzy miejscowym Romom $\mathrm{w}$ efekcie spis przeprowadzili pracownicy magistratu ${ }^{12}$. Wyniki spisu powszechnego w Czechach we fragmentarycznym elemencie komponentu narodowościowego oraz wyznaniowego zostały nagłośnione w wielu państwach europejskich, stając się atrakcyjnym newsem medialnym. Opinia publiczna została poinformowana, że w kraju, kojarzącym się $z$ pilzeńską marka motoryzacyjna S̆koda, żyje większa społeczność wyznawców (zwolenników) filozofii rycerzy Jedi ze słynnej produkcji filmowej Gwiezdne Wojny (15 070 osób) niż osób narodowości romskiej (13 150 deklaracji). Wiceprezes Czeskiego Urzędu Statystycznego S. Drapal w czasie konferencji referującej przebieg i główne wyniki spisu powszechnego zakomunikował: statystykom nie wypada oceniać, czy coś jest, czy nie jest grupa wyznaniowa; nie można przecież zaniedbać małego miasta powiatowego ${ }^{13}$.

\footnotetext{
11 [Dostęp: 10.08.2016]. Dostępny w World Wide Web: <http://bit.ly/2gel9E0>. 12 www.rp.pl/artykul/669987, [Dostęp: 10.08.2016].

13 [Dostęp: 13.08.2016]. Dostępny w World Wide Web: http://wiadomosci.dziennik.pl/swiat/artykuly/371235.
} 


\section{Komponent etniczny w spisach powszechnych państw V4 w 2011 roku}

Organizatorzy spisów powszechnych w państwach Grupy Wyszehradzkiej w części narodowościowej kwestionariuszy zastosowali różne formuły poznawcze, różne formy pytań o identyfikację narodowo-etniczna. Brzmienia pytań kwestionariuszowych wykorzystane w każdym z krajów w roku 2011 przedstawiają się następujaco:

- Polska, użycie dwóch pytań: Jaka jest Pana(i) narodowość? (Przez narodowość należy rozumieć przynależność narodowa lub etniczna - nie należy jej mylić $z$ obywatelstwem) ${ }^{14}$. Czy odczuwa Pan(i) przynależność także do innego narodu lub wspólnoty etnicznej?

- Węgry, zastosowanie dwóch pytań: Do jakiej narodowości przynależysz?15 Czy ankietowany przynależy - poza zaznaczona powyżej - do innej narodowości?

- Słowacja, pojedyncze pytanie - rubryka Narodowość; możliwość zakreślenia jednej z 14 wymienionych narodowości (słowacka, węierska, romska, rusińska, ukraińska, czeska, niemiecka, polska, chorwacka, serbska, rosyjska, żydowska, morawska, bułgarska) bądz odznaczenie opcji inna z samodzielnym wpisaniem nazwy narodowości16.

- Czechy, pojedyncze pytanie-rubryka: Narodowość. Podanie danych nie jest obowiazkowe. Można podać dwie narodowości (i pozostawione dwa puste wiersze do ewentualnego, samodzielnego uzupełnienia pierwszej i potencjalnie drugiej narodowości) ${ }^{17}$.

$14 \mathrm{~W}$ formularzu podano listę 13 ustawowych mniejszości narodowych i etnicznych (białoruska, czeska, litewska, niemiecka, ormiańska, rosyjska, słowacka, ukraińska, żydowska, karaimska, łemkowska, romska, tatarska) oraz udostępnioną odpowiedź „inna (jaka?) ...”.

$15 \mathrm{~W}$ odpowiedzi na to pytanie zamieszczono listę 18 narodowości (węgierska, bułgarska, cygańska, grecka, chorwacka, polska, niemiecka, armeńska, rumuńska, rusińska, serbska, chorwacka, słowacka, słoweńska, ukraińska, arabska, chińska, rosyjska, wietnamska) oraz pozostawiono otwarta odpowiedź inna, mianowicie Zob. [Dostęp: 14.08.2016]. Dostępny w World Wide Web: <http:// bit.ly/2g3CMKx>.

16 [Dostęp: 14.08.2016]. Dostępny w World Wide Web: <http://bit.ly/2gpJ8zk>.

17 [Dostęp: 14.08.2016]. Dostępny w World Wide Web: <http://bit.ly/2gpInX8>. 
W analizowanych państwach Grupy V4 rodzime urzędy statystyczne w opracowaniach wyników spisu z 2011 roku na określenie osób, których identyfikacja etniczna nie została w trakcie spisu poznana, zastosowały następujące kategorie językowe:

a) nem kivánt válaszolni, nincs válasz (odmowa odpowiedzi, brak odpowiedzi) - Węgry,

b) neuvedeno (nieznana) - Czechy,

c) nezistená (niewykryta) - Słowacja,

d) nieustalona-Polska.

\section{Zjawisko luki identyfikacji etnicznej w spisach powszechnych a.d. 2011}

W poniższych tabelach przedstawione zostały deklaracje mieszkańców państw należących do Grupy Wyszehradzkiej w zakresie identyfikacji narodowo-etnicznych $z$ podziałem na deklaracje kobiet i mężczyzn, $z$ wyeksponowaniem danych dotyczących zjawiska luk tej identyfikacji. W tabelach zestawiono wyniki w zakresie tożsamości narodowościowej w odniesieniu do deklaracji kobiet i mężczyzn, rezygnujących $z$ możliwości udzielenia informacji na temat swojej identyfikacji narodowej na tle osób o ustalonej identyfikacji, przynależącej do dominującej grupy narodowej, grup mniejszościowych i ewentualnie osób o dualnej tożsamości etnicznej.

Tabela 1. Identyfikacje narodowo-etniczne $\mathrm{w}$ Polsce $\mathrm{z}$ uwzględnieniem podziału na płeć (Narodowy Spis Powszechny 2011)

\begin{tabular}{|c|c|c|c|c|c|}
\hline \multirow{2}{*}{\multicolumn{2}{|c|}{$\begin{array}{c}\text { Identyfikacja } \\
\text { narodowo-etniczna }\end{array}$}} & \multicolumn{2}{|c|}{ Kobiety } & \multicolumn{2}{|c|}{ Mężczyźni } \\
\hline & & \multirow{2}{*}{\begin{tabular}{|c|}
$\begin{array}{c}\text { w liczbach } \\
\text { bezwzględ- } \\
\text { nych }\end{array}$ \\
268080 \\
\end{tabular}} & \multirow{2}{*}{$\begin{array}{c}\begin{array}{c}\text { odsetek } \\
\text { danej } \\
\text { kategorii }\end{array} \\
51,41\end{array}$} & \multirow{2}{*}{\begin{tabular}{|c|}
$\begin{array}{c}\text { w liczbach } \\
\text { bezwzgleed- } \\
\text { nych }\end{array}$ \\
253390 \\
\end{tabular}} & \multirow{2}{*}{$\begin{array}{c}\begin{array}{c}\text { odsetek } \\
\text { danej } \\
\text { kategorii }\end{array} \\
48,59\end{array}$} \\
\hline & & & & & \\
\hline \multirow{2}{*}{ ustalona } & $\begin{array}{l}\text { wyłacznie } \\
\text { polska }\end{array}$ & 18880787 & 0 & 17641424 & 48,30 \\
\hline & $\begin{array}{l}\text { polska } \\
\text { i niepolska }\end{array}$ & 429761 & 49,32 & 441679 & 50,68 \\
\hline
\end{tabular}




\begin{tabular}{|c|c|c|c|c|c|}
\hline \multirow{2}{*}{\multicolumn{2}{|c|}{$\begin{array}{l}\text { Identyfikacja } \\
\text { narodowo-etniczna }\end{array}$}} & \multicolumn{2}{|c|}{ Kobiety } & \multicolumn{2}{|c|}{ Mężczyźni } \\
\hline & & \multirow{2}{*}{\begin{tabular}{|c|}
$\begin{array}{c}\text { w liczbach } \\
\text { bezwzgledd- } \\
\text { nych }\end{array}$ \\
289171 \\
\end{tabular}} & \multirow{2}{*}{$\begin{array}{c}\begin{array}{c}\text { odsetek } \\
\text { danej } \\
\text { kategorii }\end{array} \\
48,49\end{array}$} & \multirow{2}{*}{\begin{tabular}{|c|}
$\begin{array}{c}\text { w liczbach } \\
\text { bezwzględ- } \\
\text { nych }\end{array}$ \\
307132 \\
\end{tabular}} & \multirow{2}{*}{$\begin{array}{c}\begin{array}{c}\text { odsetek } \\
\text { danej } \\
\text { kategorii }\end{array} \\
51,51\end{array}$} \\
\hline \multirow{2}{*}{ ustalona } & $\begin{array}{l}\text { wyłącznie } \\
\text { niepolska }\end{array}$ & & & & \\
\hline & $\begin{array}{l}\text { bez przyna- } \\
\text { leżności }\end{array}$ & 154 & 38,60 & 245 & 61,40 \\
\hline \multicolumn{2}{|c|}{ ludność kraju ogółem } & 19867953 & 51,59 & 18643870 & 48,41 \\
\hline
\end{tabular}

Źródło: opracowanie własne na podstawie tablicy Ludność według polskich i niepolskich identyfikacji narodowo-etnicznych i ptci $w 2011$ roku [w:] Struktura narodowo-etniczna, językowa i wyznaniowa ludności Polski. Narodowy Spis Powszechny Ludności i Mieszkań 2011, GUS, Warszawa 2015, s. 120.

Zjawisko luki identyfikacji narodowo-etnicznej w Polsce na tle państw V4 obejmuje marginalną część populacji. W najludniejszym kraju Grupy Wyszehradzkiej relatywnie niewielka grupa mieszkańców - 521 tys. spośród 38,5 mln (1,35\%) - zrezygnowała z możliwości podania swej tożsamości narodowościowej. Porównując skłonność kobiet i mężczyzn do dzielenia się danymi, które uznawane są za wrażliwe, należy zauważyć minimalną nadreprezentację mężczyzn w grupie osób niechętnie informujących o własnej identyfikacji narodowo-etnicznej podczas spisu. W zbiorze rezydentów o nieustalonej tożsamości narodowościowej mężczyźni stanowią $48,59 \%$, podczas gdy w populacji generalnej wynoszą 48,41\%. Mężczyźni są równolegle silniej reprezentowani wśród osób deklarujacych wyłącznie niepolską narodowość oraz deklarujących podwójną identyfikację (polską i niepolska). Łącznie świadczyć to może, iż w podzbiorze osób o nieustalonej tożsamości narodowościowej wśród kobiet znajduje się relatywnie znacząca liczba przedstawicielek niepolskiej oraz/bąź polskiej i niepolskiej tożsamości narodowościowej. Generalnie jednak, w Polsce, która wśród państw V4 charakteryzuje się najmniejszym odsetkiem mniejszości etnicznych, fenomen luki identyfikacji narodowościowej jest dalszoplanowy, a w ujęciu szczegółowym (różnicy w deklaracjach kobiet i mężczyzn) statystycznie nieistotny. 
Tabela 2. Identyfikacje narodowościowe na Węgrzech $z$ uwzględnieniem podziału na płeć (Népszámlálás 2011)

\begin{tabular}{|c|c|c|c|c|c|}
\hline & \multicolumn{2}{|c|}{ Kobiety } & \multicolumn{2}{|c|}{ Mężczyźni } \\
\hline & & $\begin{array}{c}\text { w liczbach } \\
\text { bezwzględ- } \\
\text { nych }\end{array}$ & $\begin{array}{c}\text { odsetek } \\
\text { danej } \\
\text { kategorii }\end{array}$ & $\begin{array}{c}\text { w liczbach } \\
\text { bezwzględ- } \\
\text { nych }\end{array}$ & $\begin{array}{c}\text { odsetek } \\
\text { danej } \\
\text { kategorii }\end{array}$ \\
\hline \multicolumn{2}{|c|}{ nieustalona } & 711547 & 50,87 & 687184 & 49,13 \\
\hline \multirow{3}{*}{$\begin{array}{c}\text { ustalo- } \\
\text { na }\end{array}$} & węgierska & 4491777 & 52,82 & 4012715 & 47,18 \\
\hline & $\begin{array}{l}\text { mniejszości } \\
\text { macierzyste }^{18}\end{array}$ & 328793 & 51,01 & 315731 & 48,99 \\
\hline & $\begin{array}{l}\text { mniejszości } \\
\text { pozostałe }\end{array}$ & 61872 & 49,81 & 62339 & 50,19 \\
\hline \multicolumn{2}{|c|}{ ludność kraju ogółem } & 5219149 & 52,52 & 4718479 & 47,48 \\
\hline
\end{tabular}

Źródło: opracowanie własne na podstawie tablicy 2.1.6.1 A népesség nemzetiség, korcsoport, legmagasabb befejezett iskolai végzettség és nemek szerint, [Dostęp: 13.08.2016]. Dostępny w World Wide Web: <http://bit.ly/2fCkais>.

Spośród państw grupy V4 Węgry są krajem o najwyższym wskaźniku feminizacji (110,6 kobiet na 100 mężczyzn). I chociaż w skali państwa odsetek kobiet przekracza $52,5 \%$ to w przypadku kategorii osób rezygnujacych $z$ udzielenia informacji na temat swej narodowości, ten odsetek jest wyraźnie niższy niż 51\%. Zjawisko nadreprezentacji mężczyzn w gronie osób, które nie chciały udzielić informacji na temat swej identyfikacji etnicznej, należy tłumaczyć większą zachowawczością części kobiet w ujawnianiu wrażliwych danych o sobie. W ujęciu przedziałów wiekowych respondentów zjawisko zaniechania manifestacji przynależności etnicznej dotyczy ponadto w większej mierze osób średniego pokolenia.

18 Hazai nemzetiségek - mniejszości narodowe, które maja swoje korzenie na Węgrzech. Nie chodzi tu o liczbę danej mniejszości, ale o długoletni związek z Węgrami. Jest ich 13: Bułgarzy, Cyganie (Romowie), Grecy, Chorwaci, Polacy, Niemcy, Ormianie, Rumuni, Rusini, Serbowie, Słowacy, Słoweńcy, Ukraińcy. 
Tabela 3. Identyfikacje narodowościowe na Słowacji $z$ uwzględnieniem podziału na płeć (Sčitanie obyvatelov, domov a bytov 2011)

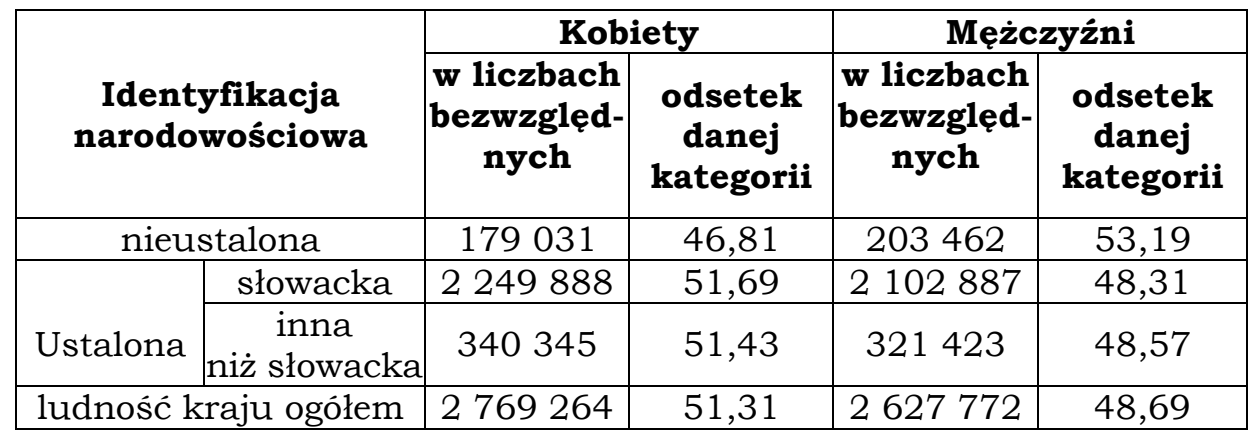

Źródło: opracowanie własne na podstawie tablicy $\mathrm{nr} 115$ Obyvatel'stvo podla pohlavia a národnosti, [Dostęp: 13.08.2016]. Dostępny w World Wide Web: http:// bit.ly/2euAXVO.

Wyniki spisu powszechnego przeprowadzonego w roku 2011 na Słowacji w zakresie komponentu etnicznego informuja o nadreprezentacji mężczyzn wśród osób o nieustalonej identyfikacji narodowościowej. W społeczności liczącej 382,5 tys. rezygnujących $z$ manifestacji tożsamości etnicznej mężczyźni stanowia $53,2 \%$, podczas gdy w populacji generalnej 48,7\%. Te dane utwierdzaja w przekonaniu, że analizując fenomen luk identyfikacji narodowościowej w państwach Grupy Wyszehradzkiej nie można pominać czynnika płci.

Zjawisko luki identyfikacji narodowo-etnicznej w Czechach na tle krajów Grupy V4 przybrało skrajna postać - aż 2,64 mln mieszkańców spośród 10,44 $\mathrm{mln}$, czyli co czwarty rezydent Republiki Czeskiej zaniechał manifestacji własnej narodowości. Należy zaznaczyć, że spośród czterech analizowanych spisów jedynie w czeskim kwestionariuszu - w rubryce dotyczacej narodowości - znalazła się informacja, że podanie danych nie jest obowiązkowe. Tego rodzaju komunikat bez watpienia nie mobilizuje osób uczestniczących w spisie do podzielenia się informacją etniczna. Porównując skłonność kobiet i mężczyzn do dzielenia się danymi, które sa przez wielu traktowane jako prywatne, należy ponownie zauważyć nadreprezentację mężczyzn w grupie osób niechętnie informujących o identyfikacji narodowościowej. 
Tabela 4. Identyfikacje narodowościowe $\mathrm{w}$ Czechach $\mathrm{z}$ uwzględnieniem podziału na płeć (Sčitání lidu, domů a bytů 2011)

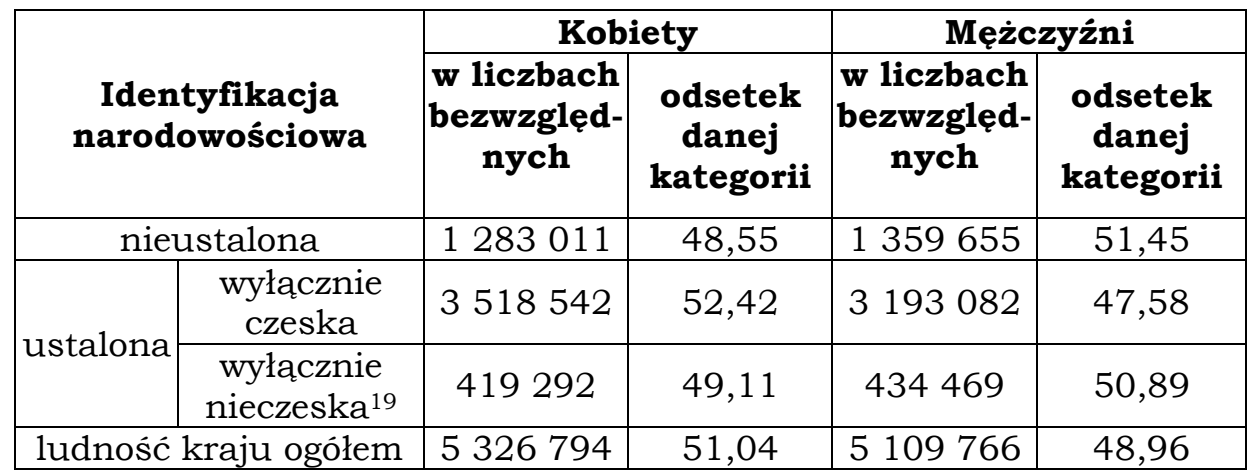

Źródło: opracowanie własne na podstawie tablicy nr 111 Obyvatelstvo podle pohlaví a podle druhu pobytu, státního občanství, zpưsobu bydlení, národnosti a náboženské viry, [Dostęp: 13.08.2016]. Dostępny w World Wide Web: $<$ http://bit.ly/2fkEJBz>.

W licznej grupie rezydentów o nieustalonej tożsamości narodowościowej mężczyźni stanowią $51,5 \%$, podczas gdy w populacji generalnej 49\%.

\section{Podsumowanie}

Odsetek osób, które zrezygnowały (z różnych powodów) z możliwości udzielenia odpowiedzi na pytanie o przynależność etniczna w ostatniej edycji spisu powszechnego (2011) w krajach Grupy Wyszehradzkiej jest silnie zróżnicowany - od 1,4\% w przypadku Polski, do 25,3\% w Czechach. Niższa skłonność ujawniania tożsamości etnicznej, jak można wnioskować, porównując przytoczone dane spisowe, wystappiła w każdym $z$ państw V4 w większej mierze wśród kobiet niż mężczyzn (w każdym z krajów Grupy Wyszehradzkiej udział kobiet wśród osób wycofujących się

19 Kategoria obejmująca deklarację reprezentantów dziesięciu mniejszości o największej liczbie (wg kolejności diaspory): morawska, słowacka, ukraińska, polska, wietnamska, niemiecka, rosyjska, śląska, węgierska, romska. 
z przyznania się do danej tożsamości narodowościowej był niższy niż udział kobiet w populacji generalnej).

Tabela 5. Luka identyfikacji narodowościowej w państwach V4: deklaracje kobiet

\begin{tabular}{|c|c|c|c|c|}
\hline $\begin{array}{c}\text { Skala zjawiska luki } \\
\text { narodowościowej } \\
\text { (odsetek populacji } \\
\text { generalnej z nie- } \\
\text { ustalona identyfi- } \\
\text { kacją etniczna) }\end{array}$ & $\begin{array}{c}\text { Państwo } \\
\text { Grupy V4 }\end{array}$ & $\begin{array}{c}\text { Odsetek ko- } \\
\text { biet wśród } \\
\text { osób o nie- } \\
\text { ustalonej } \\
\text { identyfikacji } \\
\text { narodowo- } \\
\text { sciowej }\end{array}$ & $\begin{array}{c}\text { Odsetek } \\
\text { kobiet } \\
\text { w populacj } \\
\text { i general- } \\
\text { nej kraju }\end{array}$ & $\begin{array}{c}\text { Różnica } \\
\text { w pkt. } \\
\text { procento- } \\
\text { wych }\end{array}$ \\
\hline $1,35 \%$ & Polska & $51,41 \%$ & $51,59 \%$ & $-0,18$ \\
\hline $7,09 \%$ & Słowacja & $46,81 \%$ & $51,32 \%$ & $-4,51$ \\
\hline $14,65 \%$ & Węry & $50,87 \%$ & $52,52 \%$ & $-1,65$ \\
\hline $25,32 \%$ & Czechy & $48,55 \%$ & $51,04 \%$ & $-2,49$ \\
\hline
\end{tabular}

Źródło: opracowanie własne na podstawie danych ze spisów powszechnych 2011 w Polsce, Czechach, na Węgrzech i Słowacji.

Kobiety sa tradycyjnie bardziej konserwatywne, a także częściej konformistyczne, w zauważalnie większym stopniu przywiązuja wagę do powinności państwowych (obywatelskich), a zarazem cechuja się większą zachowawczością. Równolegle we wszystkich analizowanych państwach, na etapie interpretacji wyników spisów w zakresie identyfikacji narodowościowych, pojawiły się - nie po raz pierwszy - mocne przesłanki potwierdzajace zasadę, iż przedstawiciele wielu mniejszości preferują postawę nieujawniania swojej narodowości. W świetle tej zasady oraz przytoczonych zestawień uprawnione jest sformułowanie następującej tezy: niższa skłonność ujawniania tożsamości etnicznej w grupie mniejszości narodowościowych krajów V4 dotyczy w większej części kobiet aniżeli mężczyzn.

Zainteresowanie zjawiskiem luk identyfikacji narodowościowej mobilizuje do podjęcia kolejnych, pogłębionych analiz $z$ zakresu społecznych oraz politycznych konsekwencji tego fenomenu. Uprawnione byłoby przeprowadzenie badań koncentrujących się na tym, jakie sa następstwa niepełnej wiedzy o strukturze na- 
rodowościowej państwa, w jaki sposób luki identyfikacji etnicznych wpływaja na wybrane aspekty polityki narodowościowej.

\section{Bibliografia}

\section{Źródla statystyczne}

2011. Evi Nepszamlalas. Nemzetisegi adatok, oprac. G. Vukovich, Központi Statisztikai Hivatal, Budapeszt 2014, [Dostęp: 10.08.2016]. Dostępny w World Wide Web: <http://bit.ly/2g11k5z>.

A népesség nemzetiség, korcsoport, legmagasabb befejezett iskolai végzettség és nemek szerint, [Dostęp: 10.08.2016]. Dostępny w World Wide Web: <http://bit.ly/2fCkais>.

Kwestionariusz spisowy, [Dostęp: 10.08.2016]. Dostępny w World Wide Web: <http://bit.ly/2fCkRs8>.

Obyvatel'stvo podla pohlavia a národnosti, [Dostęp: 13.08.2016]. Dostępny w World Wide Web: <http://bit.ly/2euAXVO>.

Obyvatelstvo podle pohlavi a podle druhu pobytu, státního občanství, způsobu bydlení, národnosti a náboženské víry, [Dostęp: 13.08.2016]. Dostępny w World Wide Web: <http://bit.ly/2fkEJBz>.

\section{Akty normatywne}

Rozporzadzenie (WE) Parlamentu Europejskiego i Rady nr 763/2008 $z$ dnia 9 lipca 2008 r. $w$ sprawie spisów powszechnych ludności i mieszkań, Dziennik Urzędowy Unii Europejskiej, L218/14, [Dostęp: 13.08.2016]. Dostępny w World Wide Web: <http://bit.ly/2gvaHsj>.

\section{Opracowania}

Barwiński M., Struktura narodowościowa Polski w świetle wyników spisu powszechnego z 2011 roku, „Przeglad Geograficzny” 2014, t. 86, z. 2, ISSN 0033-2143.

Gołata E., Spis ludności i prawda, „Studia Demograficzne” 2012, nr 1 (161), ISSN 0039-3134.

Krywult-Albańska M., Spis powszechny jako źródło informacji o ludności, „Studia Socjologiczne” 2012, nr 4, ISSN ISSN 0039-3371.

Kwestie spisowe a tożsamość etniczno-kulturowa autochtonicznych mniejszości na pograniczach, red. S. Jackiewicz, Wydawnictwo UwB, Białystok 2012, ISBN 978-83-7431-328-5. 
Mniejszości narodowe $i$ etniczne $w$ Polsce $w$ świetle Narodowego Spisu Powszechnego Ludności z 2011 roku, red. S. Łodziński, K. Warmińska, G. Gudaszewski, Warszawa: Wydawnictwo Naukowe Scholar, 2015, ISBN 978-83-7383-735-5.

Struktura narodowo-etniczna, językowa $i$ wyznaniowa ludności Polski. Narodowy Spis Powszechny Ludności i Mieszkań 2011, Warszawa: Główny Urząd Statystyczny, 2015, ISBN 978-83-7027-597-6.

Ścigaj P., Tożsamość narodowa: zarys problematyki, Kraków: Księgarnia Akademicka, 2012, ISBN 978-83-7638-261-6.

Witkowski J., Organizacja narodowych spisów powszechnych 2002: [Narodowy Spis Powszechny Ludności i Mieszkan 2002, Powszechny Spis Rolny 2002, oprac. pod kierunkiem Janusza Witkowskiego, Warszawa: Zakład Wydawnictw Statystycznych, 2004, ISBN 83-7027-279-7. 